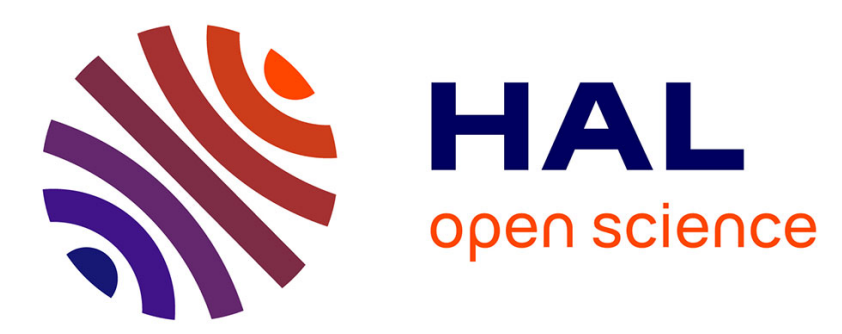

\title{
Growth and characterization of Co-doped spinels of laser interest
}

\author{
N. Kuleshov, V. Mikhailov, V. Shcherbitsky, T. Glynn, R. Sherlock
}

\section{To cite this version:}

N. Kuleshov, V. Mikhailov, V. Shcherbitsky, T. Glynn, R. Sherlock. Growth and characterization of Co-doped spinels of laser interest. Journal de Physique IV Proceedings, 1994, 04 (C4), pp.C4-612-C4612. 10.1051/jp4:19944162 . jpa-00252619

\section{HAL Id: jpa-00252619 https://hal.science/jpa-00252619}

Submitted on 1 Jan 1994

HAL is a multi-disciplinary open access archive for the deposit and dissemination of scientific research documents, whether they are published or not. The documents may come from teaching and research institutions in France or abroad, or from public or private research centers.
L'archive ouverte pluridisciplinaire HAL, est destinée au dépôt et à la diffusion de documents scientifiques de niveau recherche, publiés ou non, émanant des établissements d'enseignement et de recherche français ou étrangers, des laboratoires publics ou privés. 


\title{
Growth and characterization of Co-doped spinels of laser interest
}

\author{
N.V. KULESHOV, V.P. MIKHAILOV, V.G. SHCHERBITSKY, T.J. GLYNN* and R. SHERLOCK* \\ Institute for Applied Physics Problems, Belarusian State University, Minsk 220064, Belarus \\ * University College Galway, Ireland
}

\begin{abstract}
The luminescence properties of tetrahedrally coordinated $\mathrm{Co}^{2+}\left(d^{7}\right)$ ion in spinels were studied in [1,2]. A combination of broad luminescence transitions coupled with a large oscillator strength makes $\mathrm{Co}^{2+}$-doped spinels interesting candidates for tunable solid-state lasers in the visible and near infrared. In this paper optical absorption and luminescence of divalent cobalt have been studied in $\mathrm{MgAl}_{2} \mathrm{O}_{4}$ (MALO) and $\mathrm{ZnGazO}_{4}$ ( $\mathrm{ZGO}$ ) spinels. The crystals were grown by the Vierneuil (MALO) and flux (ZGO) methods. The absorption bands at 7200,17000 and $21000 \mathrm{~cm}^{-1}$ are assigned to transitions from the ${ }^{4} \mathrm{Az}_{2}\left({ }^{4} \mathrm{~F}\right)$ ground state to the ${ }^{4}{ }_{\mathrm{T}}\left({ }^{4} \mathrm{~F}\right)$, ${ }^{4} \mathrm{~T}_{1}\left({ }^{4} \mathrm{P}\right)$ and ${ }^{2} \mathrm{~T}_{1}\left({ }^{2} \mathrm{P}\right)$ excited states of tetrahedrally coordinated $\mathrm{Co}^{2+}$, respectively.

Saturation of the Co ${ }^{2+}$ absorption at $540 \mathrm{~nm}$ was measured in MALO and peak absorption cross section for ${ }^{4} \mathrm{Az}_{2}\left({ }^{4} \mathrm{~F}\right)-{ }^{4} \mathrm{~T}_{1}\left({ }^{4} \mathrm{P}\right)$ transition was estimated to be $4 \times 10^{-18} \mathrm{~cm}^{2}$. The broad luminescence bands observed in the visible at $670 \mathrm{~nm}$ and in the near infrared at 880 $\mathrm{nm}$ and $1290 \mathrm{~nm}$ are assigned to transitions from the ${ }^{4} \mathrm{~T}_{1}\left({ }^{4} \mathrm{P}\right)$ excited level to the lower lying ${ }^{4} \mathrm{Aa}_{2}\left({ }^{4} \mathrm{~F}\right),{ }^{4} \mathrm{~T}_{2}\left({ }^{4} \mathrm{~F}\right)$ and ${ }^{4} \mathrm{~T}_{1}\left({ }^{4} \mathrm{~F}\right)$ levels, respectively. The temperature behavior of the emission intensity and decay time in MALO indicated strong luminescence quenching at room temperature. The emission decay time in ZGO varied from $0.85 \mu$ s at $77 \mathrm{~K}$ to $1.1 \mu \mathrm{s}$ at room temperature.

No spectroscopic evidence for octahedrally coordinated $\mathrm{Co}^{2+}$ has
\end{abstract} been observed.

\section{References}

1. J.F. Donegan, F.G. Anderson, F.J. Bergin, T.J. Glynn, and G.F. Imbusch, Phys. Rev. B, 45 (1992) 563.

2. T. Abritta and F.H. Blak, J. Lumin. 48 \& 49 (1991) 558. 